UDC 599.32:591.9(477.87)

\title{
LIVING ON THE EDGE: DISTRIBUTION PATTERNS OF STEPPE MAMMALS IN TRANSCARPATHIA (UKRAINE)
}

\author{
Z. Barkaszi, I. Zagorodniuk \\ National Museum of Natural History, NAS of Ukraine \\ 15, Bohdan Khmelnytsky St., Kyiv 01030, Ukraine \\ e-mail: zlbarkasi@ukr.net
}

Barkaszi Z., Zagorodniuk I. Living on the edge: distribution patterns of steppe mammals in Transcarpathia (Ukraine). Studia Biologica, 2018: 12(3-4); 75-94 •DOI: https://doi.org/10.30970/ sbi.1203.573

We analysed the composition of the steppe assemblage in the mammal fauna of Transcarpathia (Ukraine), which is represented by three rodent species such as the European ground squirrel Spermophilus citellus, the common hamster Cricetus cricetus, and the steppe mouse Mus spicilegus. These species have not been considered in the composition of the local fauna or they were mentioned only in general checklists, or even with obvious mistakes in descriptions of both key characters and record localities. Here we present detailed descriptions of distribution of each steppe species based on actual record localities as well as ecological and biogeographic features. In total, we have generalized data on 13 record localities of Spermophilus citellus, 7 of Cricetus cricetus, and 8 of Mus spicilegus. We also revealed and described general trends in the distribution of these species: all of them occur in the lowland part of Transcarpathia between the valleys of the Tisza and Latorica rivers and adjacent areas. Generally, steppe species in Transcarpathia are related to anthropogenically transformed biotopes: the European ground squirrel mainly occurs along banks of dammed rivers in zones of floods, while the common hamster and the steppe mouse are both related to agricultural lands. The absence of natural populations in indigenous biotopes and, in fact, the absence of typical key steppe habitats suggest that steppe species appeared in Transcarpathia as the result of expansion from their main geographic range as suitable habitats gradually appeared at the range periphery. The closest centre of distribution of each species is located beyond the studied region, namely in the Great Hungarian Plain, and the records described here are marginal: they are instable and attributed to the zones of range pulsation, which depends on climatic factors and current landscape features of the lowland part of Transcarpathia. The state and dynamics of range-edge populations of steppe species in Transcarpathia might be largely affected by the hydrological regime,

(C) 2018 Z. Barkaszi et al.; Published by the Ivan Franko National University of Lviv on behalf of Біологічні Студії / Studia Biologica. This is an Open Access article distributed under the terms of the Creative Commons Attribution License (http://www.budapestopenaccessinitiative.org/ and Creative Commons Attribution 4.0 License), which permits unrestricted reuse, distribution, and reproduction in any medium, provided the original work is properly cited.

ISSN 1996-4536 (print) • ISSN 2311-0783 (on-line) • Біологічні Студії / Studia Biologica • 2018 • Том 12/№3-4 • С. 75-94 
wintering conditions, human activity, etc., as well as by "edge effects" that usually take place in fragmented populations. The influence of such processes probably could explain the low abundance and rarity of steppe species in the region, and, in the same time, makes topical the issue of their conservation. At present, conservation issues especially concern two species, namely the European ground squirrel and the common hamster, which are keystone species in steppe and forest steppe ecosystems.

Keywords: steppe fauna, rodents, rare species, biotopes, Transcarpathia, Ukraine

\section{INTRODUCTION}

Species diversity is largely influenced by landscape heterogeneity, in each type of which historically unique zonal and local communities emerge. The relatively high diversity of landscapes and ecological communities is particularly common for mountainous regions and adjacent territories, which is due to several ecological factors including geographical and altitudinal zonation, high density of watercourses, ecotone effects, artificially transformed biotopes, etc. (e.g., [39, 51]).

The Carpathian Mountains and adjacent regions are located at the junction of forest, forest steppe, and steppe belts of Europe. In a biogeographic context, the Carpathian Basin draws a special interest since it is the westernmost fragment of the Great Eurasian Steppe. Steppe communities that exist here are relatively isolated and they are surrounded by mountain systems having a connection with the East European steppe only through the northern Balkans [30]. Through this relatively narrow contact zone elements of the steppe fauna could enter the Carpathian Basin and disperse further north, including the territory of Transcarpathia (i.e. Zakarpattia Oblast), which is the most remote northern part of the Great Hungarian Plain (Fig. 1). Such remoteness of Transcarpathia from the steppe faunal core and the immediate proximity of mountain assemblages are the main factors drawing interest to the analysis of the species composition of lowland communities, particularly to the presence and distribution patterns of steppe species represented by range-edge populations in the region.

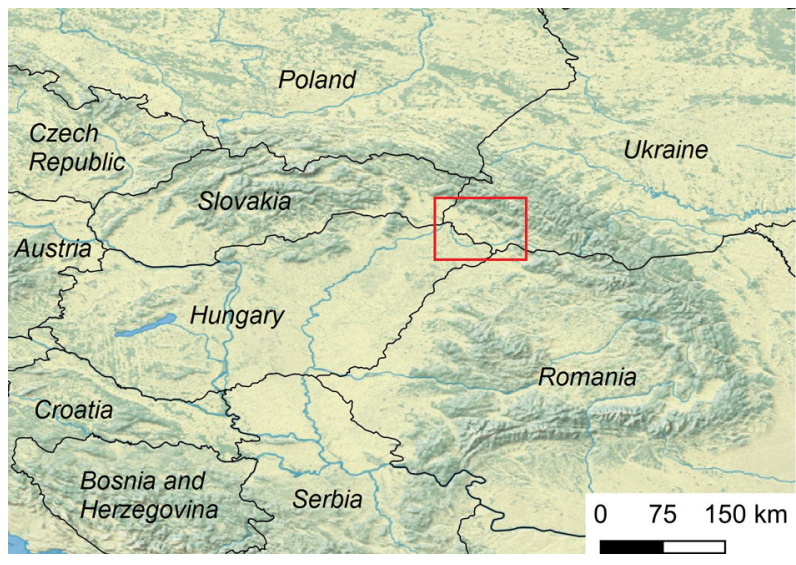

Fig. 1. The location of the Transcarpathian region (red frame) within the Carpathian Basin

Рис. 1. Розташування Закарпатського регіону (червона рамка) в межах Карпатського басейну

The distribution of steppe species in plains is usually determined by the arrangement of not only the steppe biome's borders itself, but also of river valleys [17, 25].

ISSN 1996-4536 (print) • ISSN 2311-0783 (on-line) • Біологічні Студії / Studia Biologica • 2018 • Том 12/№3-4 • С. 75-94 
Research on steppe faunal assemblages allowed formulating the concept of "steppe faunal core" (SFC), which in Eastern Europe includes more than 30 mammalian species distributed mainly within the steppe belt but some of them also entering the forest steppe [56]. The SFC naturally decreases westward by the number of species, especially at such important biogeographic barriers as large river valleys, which generally cut the steppe belt from north to south into several "fragments". Earlier, it was shown that the East European SFC consists of 28 mammalian species to the west from the Volga, 16 from the Don, 12 from the Dnipro (Dnieper), 10 from the Southern Bug, and only 7 from the Danube [56].

The Transcarpathian fauna in the context of presence and distribution of steppe species has not been analysed before due to several reasons. Firstly, the region is largely isolated from the steppe belt (both from the Northern Black Sea Region and the Balkans), and, secondly, steppe species are usually not considered in its fauna's composition. Besides, the lack of attention to the steppe elements in the region is caused not only by high rarity of these animals but also because more diverse mountain communities have drawn much more research interest. Therefore, steppe species in the fauna of Transcarpathia were either not considered at all or indicated ambiguously $[3,46,47,50,52]$.

The aim of our research was to analyse the complete available dataset on the exact record localities, geographical distribution, and biotope selection of steppe mammal species in the Transcarpathian fauna, to describe species ranges and current state of population, as well as to analyse changes in the composition and distribution of steppe species in the region.

\section{MATERIAL AND METHODS}

Data for analysis of the Transcarpathian steppe mammal assemblage were collected from several sources. Firstly, all available museum collections were examined, including the mammal collection of the National Museum of Natural History, NAS of Ukraine, Kyiv (NMNHU), State Natural History Museum, NAS of Ukraine, Lviv (SNHM) and three zoological museums functioning at Ukrainian national universities in Kyiv (ZMKU), Lviv (ZMLVU), and Uzhhorod (UZZM).

A significant part of data was collected by critical analysis of literature sources, interviewing of local zoologists and interested people (i.e. teachers, gamekeepers, hunters), as well as during field expeditions in 2004-2018 to the places of supposed occurrence of steppe species with suitable biotopes. In total, ca. 40 positive interviews of colleagues and residents were conducted.

A database was created that includes all records and record localities of steppe mammal species, which was applied to construct maps of distribution by QGIS software using layers of own creation, Google map data and public domain maps (Natural Earth).

The taxonomy and nomenclature used in this paper follows the scheme proposed earlier for the mammal fauna of Ukraine [60].

\section{RESULTS AND DISCUSSION}

In subsequent sections, we present the composition of steppe faunal assemblage in Transcarpathia. Each species is described according to a common scheme: 1) general information, 2) signs of presence and field diagnostics, and 3) former and current records.

ISSN 1996-4536 (print) • ISSN 2311-0783 (on-line) • Біологічні Студії / Studia Biologica • 2018 • Том 12/№3-4 • C. 75-94 


\section{Composition of the steppe faunal assemblage in Transcarpathia}

According to the latest surveys of the mammalian fauna of the Ukrainian Eastern Carpathians $[2,3,63]$ and other publications [22, 45], the presence of 10 typical steppe species of mammals could be expected in Transcarpathia:

Order Rodentia (9 species):

- European ground squirrel, Spermophilus citellus (Linnaeus, 1766); • Podolian ground squirrel, Spermophilus odessanus Nordmann, 1840; • Nordmann birch mouse, Sicista loriger (Nathusius, 1840); • lesser mole rat, Nannospalax leucodon (Nordmann, 1840); • Balkan mole rat, Spalax graecus Nehring, 1898; • Podolian mole rat, Spalax zemni Erxleben, 1777; • common hamster, Cricetus cricetus (Linnaeus, 1758); • grey dwarf hamster, Cricetulus migratorius (Pallas, 1773); • steppe mouse, Mus spicilegus Petényi, 1882;

Order Carnivora (1 species):

- steppe polecat, Mustela eversmanii Lesson, 1827.

Data collected during recent years clearly suggest the presence of only three of the 10 possible steppe species, namely of the European ground squirrel (Spermophilus citellus), common hamster (Cricetus cricetus), and steppe mouse (Mus spicilegus), representing three families, Sciuridae, Cricetidae, and Muridae. It is not by chance since at range edges and under unfavourable conditions the fauna is represented exclusively by species of different genera or even families, described as the "principle of monotypization of higher taxa" [62].

The occurrence of the European ground squirrel in fauna of Transcarpathia was first described with record details by Reshetnyk [42]. Later, the species was mentioned without details in different general fauna surveys (the latest by Bashta and Potish [3]), and its range was recently reconstructed with information on then known records [64]. The common hamster was usually listed for the local fauna either based on ambiguous records and without description and mapping of distribution $[3,43]$ or it was not mentioned at all [31, 34]. The first report on records of M. spicilegus appeared in 2007 [3], although accompanied by slightly ambiguous descriptions, which allows suggesting that the species might have remained undiscovered in the region until recently. The idea of the absence of the steppe mouse in the fauna of Transcarpathia was supported earlier by the results of analysis of old mice samples [29].

The presence of the steppe polecat (M. eversmanii) suggested earlier in the Transcarpathian fauna (e.g., $[52,55])$ is questionable. Firstly, current records of the species are unknown and museum specimens from Transcarpathia in zoological collections of Ukraine are absent too [13]. Secondly, analysis of literature sources revealed that localities of the species' records presented in fauna surveys (e.g., [3, 52, 55, 63]) originated from Abelentsev [1], who, however, also had no actual materials and presented records referring to two older sources. In one publication cited by Abelentsev, there is no information on the steppe polecat in Transcarpathia at all [12], while searches for the other source (Konyukhovich, 1953 as cited in [1]), were unsuccessful. However, we suggest that all records of the polecat in Transcarpathia originate only from the latter source. Currently, there is no evidence that the steppe polecat is present in fauna of Transcarpathia.

The European ground squirrel, Spermophilus citellus (Linnaeus, 1766)

General information. The European ground squirrel in one of the least studied rodents in the Ukrainian fauna. The species is distributed in Central and Southern Europe,

ISSN 1996-4536 (print) • ISSN 2311-0783 (on-line) • Біологічні Студії / Studia Biologica • 2018 • Том 12/№3-4 • С. 75-94 
including the countries of the European Union neighbouring with Ukraine [24; 40]. The ground squirrel reaches the territory of Ukraine by three range fragments including the Transcarpathian one [61]. The occurrence of the species in Transcarpathia had been debated for a long time (e.g., [50, 46, 47]), although it was strongly suggested [41].

According to old sources, the European ground squirrel was a common species in the Tisza river's valley in the late 19th century [35]. However, it was "first" discovered in Transcarpathia only in 1964 near Chop [42], where the species occupied old dams along the Tisza and Latorica rivers and had an abundance of ca. 25-30 specimens per hectare. Later, the European ground squirrel was mentioned only formally referring to Reshetnyk's works (e.g., in [3, 21]). The first revision of the species' distribution in the region was carried out in 2010 with our participation [64], which is here complemented by recently obtained data.

Signs of presence and field diagnostics. If present, the species is easily noticeable and well known to locals, especially herders and hunters. Interviewing of locals usually gives positive results: they easily recognise and describe the species by its typical stance (and sometimes its voice too) and characteristic vertical burrows.

Records. We found 24 specimens from 4 localities in museum collections (Table 1). All specimens were collected in 1964 and 1966 and they are deposited in the mammal collection of NMNHU. In total, we have knowledge about 13 record localities of the European ground squirrel, the majority of which were reported by our zoologist colleagues from the Uzhhorod National University. Practically all record localities were reported from lowlands of southwest Transcarpathia, the area located along the state border. Field research conducted in 2004-2006 and 2014-2018 between Uzhhorod and Chop, Chop and Berehovo, and Berehovo and Khust were unsuccessful further suggesting the high rarity of the species. Published data are extremely scarce: Reshetnyk [42] recorded the species in the vicinities of Chop. Later, in the survey of the mammal fauna of Transcarpathia, another record from "Selmentsi," Uzhhorod Region was reported [3].

The common hamster, Cricetus cricetus (Linnaeus, 1758)

General information. The common hamster is a rare steppe mammal species that has been shown to display a clear tendency of population decline and range contraction during recent decades in Ukraine $[31,43,57]$ as well as generally in Europe $[26,38,49,54]$. In the region of the Ukrainian Carpathians, the species' distribution is restricted to piedmont and adjacent lowland areas of Ciscarpathia (i.e. Prykarpattia) and Bukovina [43].

Regarding Transcarpathia, the status and distribution of the common hamster have been generally debated. For instance, Turyanin $[52,53]$ described the species for "lowland forest steppe areas of all Ciscarpathian regions" (p. 103), but did not mention even a single record of the species for Transcarpathia. The common hamster is not listed either for Transcarpathia in the latest surveys of the Ukrainian mammal fauna [34, 57]. Some information, although, again, without any specific description or cartographic data, is given in the latest survey of the mammal fauna of Transcarpathia [3]. The authors of this survey stated that the common hamster occurs in various secondary biotopes along the Tisza and Latorica rivers. However, on the added map, they indicated that the species is distributed in the entire lowland part of Transcarpathia despite their statement that the hamster is extremely rare in the region. On the other hand, according to the Red Data Book of Ukraine (RDBU), the common hamster is absent in Transcarpathia at all [31].

ISSN 1996-4536 (print) • ISSN 2311-0783 (on-line) • Біологічні Студії / Studia Biologica • 2018 • Том 12/№3-4 • C. 75-94 
Table 1. Records of the European ground squirrel (S. citellus) in Transcarpathia Таблиця 1. Знахідки ховраха європейського (S. citellus) на Закарпатті

\begin{tabular}{|c|c|c|c|c|}
\hline Region & Locality & Year & Record details & Data source* \\
\hline \multirow[t]{12}{*}{ Uzhhorod } & Uzhhorod & 1965 & $\begin{array}{l}1 \text { collection specimen } \\
\text { (study skin No. 11864) }\end{array}$ & $\begin{array}{l}\text { *collection of NMNHU, } \\
\text { leg. E. Reshetnyk }\end{array}$ \\
\hline & -unknown- & 1966 & $\begin{array}{l}1 \text { museum specimen } \\
\text { (study skin and skull No. 5386) }\end{array}$ & $\begin{array}{l}\text { *collection of UZZM, } \\
\text { leg. E. Reshetnyk and } \\
\text { O. Vaitsekhovska }\end{array}$ \\
\hline & Kholmok & 2002 & observation of animals & $\begin{array}{l}\text { *T. Dudynsky, P. Lovas, } \\
\text { pers. com. }\end{array}$ \\
\hline & Kontsovo & 2002 & $\begin{array}{l}\text { many burrows revealed, } \\
\text { one specimen caught } \\
\text { by a hunting dog }\end{array}$ & $\begin{array}{l}\text { *T. Dudynsky, P. Lovas, } \\
\text { pers. com. }\end{array}$ \\
\hline & Haloch & 1985-90 & observation of animals & $\begin{array}{l}\text { * T. Dudynsky, P. Lovas, } \\
\text { pers. com. }\end{array}$ \\
\hline & \multirow[t]{2}{*}{ Komarivtsi } & 1966 & $\begin{array}{l}6 \text { museum specimens ( } 5 \text { study } \\
\text { skins and } 4 \text { skulls in UZZM } \\
\text { No. } 5380(15), 5382,5382^{* 1} \text {, } \\
5685,5387 \text { and } 1 \text { study skin } \\
\text { and skull in NMNHU No. } 5685 \text { ) }\end{array}$ & $\begin{array}{l}{ }^{*} \text { collections of UZZM } \\
\text { and NMNHU, } \\
\text { leg. E. Reshetnyk }\end{array}$ \\
\hline & & 1985-90 & observation of animals & $\begin{array}{l}\text { *T. Dudynsky, P. Lovas, } \\
\text { pers. com. }\end{array}$ \\
\hline & \multirow[t]{2}{*}{$\begin{array}{l}\text { Mali } \\
\text { Selmentsi }\end{array}$} & 1985-90 & observation of animals & $\begin{array}{l}\text { *T. Dudynsky, P. Lovas, } \\
\text { pers. com. }\end{array}$ \\
\hline & & 2006 & $\begin{array}{l}\text { burrows revealed on a pasture, } \\
\text { interviewing of locals }\end{array}$ & Bashta and Potish, 2007 \\
\hline & Solomonove & 1966 & $\begin{array}{l}10 \text { museum specimens (study } \\
\text { skins and skulls No. } 5681-5684 \text {, } \\
5686-5691 \text { ) }\end{array}$ & $\begin{array}{l}\text { *collection of NMNHU, } \\
\text { leg. E. Reshetnyk }\end{array}$ \\
\hline & Chop & 1964 & $\begin{array}{l}5 \text { museum specimens (study } \\
\text { skins and skulls No. 2853-2857) }\end{array}$ & $\begin{array}{l}\text { *collection of NMNHU, } \\
\text { leg. E. Reshetnyk }\end{array}$ \\
\hline & Solovka & 2003 & observation of animals & $\begin{array}{l}\text { *T. Dudynsky, P. Lovas, } \\
\text { pers. com. }\end{array}$ \\
\hline \multirow[t]{3}{*}{ Berehovo } & Batovo & 2003 & observation of animals & $\begin{array}{l}\text { *T. Dudynsky, P. Lovas, } \\
\text { pers. com. }\end{array}$ \\
\hline & Borzhava & 2006 & $\begin{array}{l}\text { observation of a ground squirrel } \\
\text { near the Vérke channel }\end{array}$ & B. Dracskó, pers. com. \\
\hline & Vary & 1950s & interviewing of elderly locals & N. Mátyus, pers. com. \\
\hline Vynohradiv & Perekhrestia & 1940s & interviewing of elderly locals & T. Héder, pers. com. \\
\hline [Transcarpathia] & -unknown- & $?$ & $\begin{array}{l}1 \text { museum specimen } \\
\text { (study skin No. 8) }\end{array}$ & $\begin{array}{l}{ }^{*} \text { collection of UZZM, } \\
\text { leg. ? }\end{array}$ \\
\hline
\end{tabular}

* Records listed in our previous review [64]

* Знахідки, вказані у нашому попередньому огляді [64]

1 The date of record on the label of this specimen is "25.02[sic!].1966" and its inventory number indicated here as "No. 5382*" is actually "No. 5382" on the label, i.e. the same as the number of the previous specimen. Probably, these are mistakes made during copying of the original label

ISSN 1996-4536 (print) • ISSN 2311-0783 (on-line) • Біологічні Студії / Studia Biologica • 2018 • Том 12/№3-4 • С. 75-94 
Reliable records of the species in the region have not been published, which also indicates the lack of data and insufficient research into the hamster's distribution in the region. However, during recent years we have received more and more reports on records of the species and even its relatively high abundance in some locations. The increase of abundance is probably due to a population outbreak, which occurs periodically in this species [14, 37]. Such population growth was observed in 2012-2016 with a subsequent decline in Uzhhorod Region (V. Chumak, personal communication).

Signs of presence and field diagnostics. Since the common hamster occurs mainly in agricultural lands and behaves quite aggressively, its presence is well known to locals. Sightings of hamsters and cases of trappings were reported from several sources (Table 2).

Table 2. Records of the common hamster (C. cricetus) in Transcarpathia Таблиця 2. Знахідки хом'яка звичайного (C. cricetus) на Закарпатті

\begin{tabular}{|c|c|c|c|c|}
\hline Region & Locality & Year & Record details & Data source \\
\hline \multirow[t]{4}{*}{ Uzhhorod } & Chop & 1966 & $\begin{array}{l}1 \text { museum specimen (study skin and } \\
\text { skull No. } 5696 \text { ) }\end{array}$ & $\begin{array}{l}\text { collection of NMNHU, } \\
\text { leg. E. Reshetnyk }\end{array}$ \\
\hline & \multirow[t]{2}{*}{ Korytniany } & 2005-18 & $\begin{array}{l}\text { observation of animals, roadkills, and } \\
\text { settlements in kitchen gardens and } \\
\text { fields, also many hamsters were hunted } \\
\text { by domestic cats }\end{array}$ & V. Chumak, pers. com. \\
\hline & & 2012 & $\begin{array}{l}2 \text { museum specimens (skulls without } \\
\text { inventory ID) }\end{array}$ & $\begin{array}{l}\text { working collection of } \\
\text { the authors stored } \\
\text { at NMNHU, leg. } \\
\text { V. Chumak }\end{array}$ \\
\hline & Kholmok & 1998 & $\begin{array}{l}\text { a dead animal found in a field along } \\
\text { the railway }\end{array}$ & V. Gleba, pers. com. \\
\hline \multirow[t]{2}{*}{ Mukachevo } & \multirow[t]{2}{*}{ Rakoshyno } & 1995-96 & $\begin{array}{l}\text { abundant on crop fields, locals killed } \\
\text { may animals as pests often by filling } \\
\text { the burrows with water }\end{array}$ & R. Kish, pers. com. \\
\hline & & 2017 & $\begin{array}{l}\text { roadkills between Mukachevo and } \\
\text { Uzhhorod }\end{array}$ & R. Kish, pers. com. \\
\hline \multirow[t]{2}{*}{ Berehovo } & Velyka Bakta & $1947-48$ & $\begin{array}{l}10 \text { museum specimens (fluid preserved } \\
\text { specimens No. } 164-167 \text {; study skins } \\
\text { and skulls No. } 3733,3734,3736,3737 \text {, } \\
3750 \text {; study skin No. } 6281 \text { ) }\end{array}$ & $\begin{array}{l}\text { collection of NMNH, } \\
\text { leg. I. Sokur }\end{array}$ \\
\hline & Vary & 2018 & field next to an old orchard & N. Mátyus, pers. com. \\
\hline Vynohradiv & Perekhrestia & $1940 s$ & interviewing of elderly locals & T. Héder, pers. com. \\
\hline
\end{tabular}

Curiously, in some Ukrainian speaking villages of Mukachevo Region, the local name of the hamster is "hyrchyk" (Ukr.: «гирчик»), which is practically the ukrainized reproduction of the species' Hungarian common name "hörcsög." This may indicate the long-time presence of the hamster in such villages, at least since the 19th century, when the region was a part of Hungary.

ISSN 1996-4536 (print) • ISSN 2311-0783 (on-line) • Біологічні Студії / Studia Biologica • 2018 • Том 12/№3-4 • C. 75-94 
In addition to reports received from colleagues and locals, we also conducted field research in order to find hamsters in locations beyond the reported ones, but without positive results. Museum specimens of the common hamster from Transcarpathia are deposited mainly in the mammal collection of NMNHU, most of which were collected in the 1940s and 1960s.

Records. The list of records includes museum specimens and records reported by zoologist colleagues and local residents (Table 2). In total, we have information on 7 record localities of the species.

\section{The steppe mouse, Mus spicilegus Petényi, 1882}

General information. The steppe mouse is a common species in the fauna of the Carpathian Basin, including the countries neighbouring with Transcarpathia such as Slovakia [8, 9, 23], Hungary [5] and Romania [4]. For Transcarpathia, the steppe mouse was first mentioned in 1934 from the floodplain of the Borzhava river, namely from vicinities of Velyki Komiaty, Vynohradiv Region [48]. However, further revision of specimens revealed that they belong to $M$. musculus [29]. The steppe mouse was not mentioned at all in publications of the second half of the 20th century until the latest review of the mammal fauna of Transcarpathia [3]. Although, it can be also related to the fact that the species status of the steppe mouse was accepted in Ukraine only in 1989 [33], shortly after it took place in Europe [6].

However, the description of the steppe mouse in the above-mentioned fauna review [3: 156] contains several contradictive statements, including 1) the necessity of discrimination of $M$. spicilegus from Apodemus agrarius, 2) the uncommonly large size of mounds described ( $4 \mathrm{~m}$ in diameter and $0.8 \mathrm{~m}$ in height), and 3 ) the construction of mounds from grass and remains of plants mixed up with soil. In practice, the issue is to discriminate the steppe mouse from $M$. musculus, the size of mounds is far smaller and their structure also differs from that described in the mentioned source. Therefore, the authors of the review might describe some crop residues left in the fields by farmers instead of mounds built by the steppe mouse.

Signs of presence and field diagnostics. In the field, there are two reliable signs of the species' presence: firstly, the specific mounds built by the animal, and secondly, if the animal was captured, the absence of musky scent which is a very specific feature of its sibling species, the house mouse, M. musculus. According to our data, mounds of the steppe mouse in Transcarpathia (Fig. 2-3) do not differ substantially from those studied in other regions of Ukraine (we have examined hundreds of them). Usually, they are located on fallows, ruderal lands, field edges, and harvested crop fields (sunflower, corn, and wheat). Small ("young") mounds have conical shape, they are $20-70 \mathrm{~cm}$ in diameter and $25-35 \mathrm{~cm}$ in height, while "older" and well-constructed mounds (especially second-year ones) are elongated, $100-160 \mathrm{~cm}$ in length and up to $40 \mathrm{~cm}$ in height. Mounds represent, basically, plant materials collected by the animals and covered by a ca. $5-7 \mathrm{~cm}$ thick layer of ground. Around the mound, several (usually 10-15) pits can be found from which the mice dug out the soil. The inner structure of the examined mounds in Transcarpathia is usually represents three well distinguished layers: closest to the ground and in the centre of the mound we found ears of grasses, mainly of Setaria viridis, covered by a relatively thick layer of hay-like plant material, while the outer layer represents a ca. 5-7 cm thick cover of ground. Stocks of grains, achene, beans, siliques, follicles, etc. were not revealed, which allows suggesting that mounds serve rather for isolation (thermo- and hydro-) than food stores for winter.

ISSN 1996-4536 (print) • ISSN 2311-0783 (on-line) • Біологічні Студії / Studia Biologica • 2018 • Том 12/№3-4 • С. 75-94 
Records of the steppe mouse in Transcarpathia have yet been reported only based on the species' specific mounds, and attempts of trapping animals have been unsuccessful. Currently, there are data about records of mounds from 8 localities (Table 3).

Table 3. Records of the steppe mouse (M. spicilegus) in Transcarpathia Таблиця 3. Знахідки миші курганцевої (M. spicilegus) на Закарпатті

\begin{tabular}{ll|l|ll}
\hline Region & Locality & Year & Record details & Data source \\
\hline Uzhhorod & Palad-Komarivtsi & $2005-07$ & ca. 10 mounds revealed & {$[3]$} \\
& Mali Heivtsi & $2005-07$ & 4 mounds revealed & {$[3]$} \\
& Mali Selmentsi & $2005-07$ & 7 mounds revealed & {$[3]$} \\
Berehovo & Haloch & $2005-07$ & 11 mounds revealed & {$[3]$} \\
& Hut & 2018 & $\begin{array}{l}14 \text { mounds revealed on fallows, harvested } \\
\text { corn fields, vineyards }\end{array}$ & our data \\
& Mala Byihan & 2018 & $\begin{array}{l}\text { 9 mounds revealed on fallows and harvested } \\
\text { corn fields }\end{array}$ & our data \\
& Rafailovo & 2015 & $\begin{array}{l}\text { ca. 10 mounds revealed on corn fields during } \\
\text { harvesting } \\
\text { ca. 10 mounds revealed on corn fields during } \\
\text { hakrvesting }\end{array}$ & our data \\
& Barkasovo & 2015 & our data
\end{tabular}

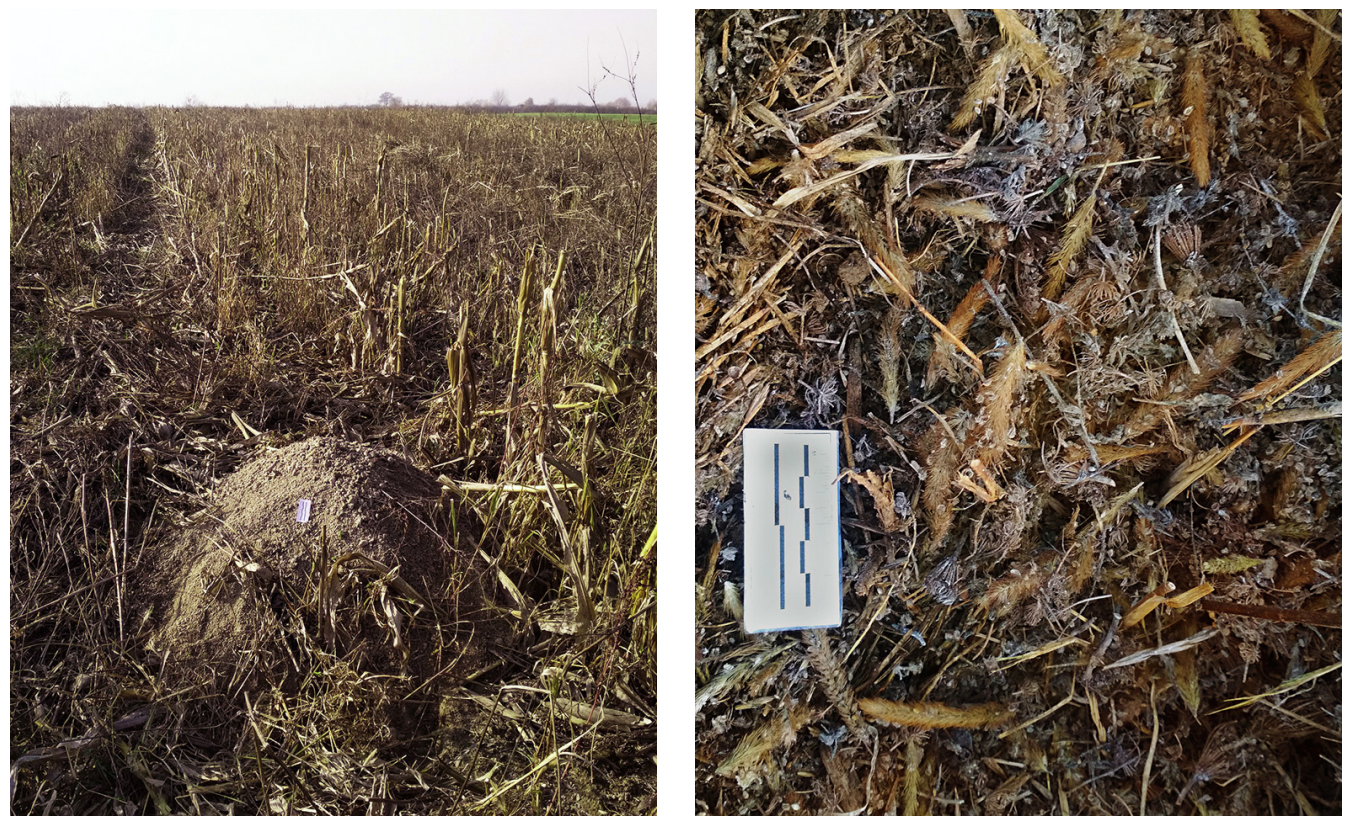

Fig. 2. A mound of the steppe mouse on a harvested cornfield (left) and ears of Setaria viridis found inside the mound (right). Near Hut, Berehovo Region in November 2018. Scale $5 \mathrm{~cm}$

Рис. 2. Курганчик миші степової на прибраному кукурудзяному полі (зліва) та колоски Setaria viridis, знайдені всередині курганця (справа). Околиці с. Гут Берегівського р-ну. Листопад 2018. Шкала $5 \mathrm{~cm}$

ISSN 1996-4536 (print) •ISSN 2311-0783 (on-line) • Біологічні Студії / Studia Biologica • 2018 • Том 12/№3-4 • C. 75-94 

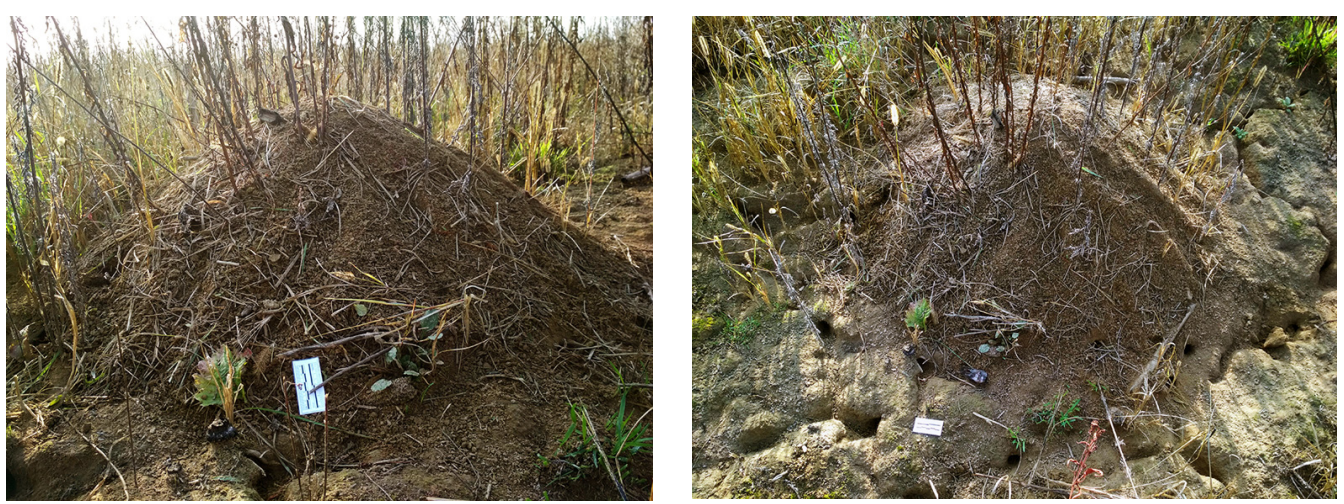

Fig. 3. A mound found on a fallow (left) and surrounded by pits from which mice burried out the soil to build the mound (right). Near Hut, Berehovo Region in November 2018. Scale $5 \mathrm{~cm}$

Рис. 3. Курганчик, знайдений на перелозі (зліва) і оточений ямками, з яких миші викопали ґрунт для побудови курганця (справа). Околиці с. Гут Берегівського р-ну. Листопад 2018. Шкала 5 см

\section{Distribution and changes in abundance of the studied species}

Analysis of all available data, often highly scarce due to the rarity of the studied species, allows reconstructing the distribution range of steppe species in Transcarpathia. In particular, data show that the range of the European ground squirrel has two segments in the region covering biotopes along the state border (Fig. 4), which are practically the continuation of the species' main range located in the Great Hungarian Plain $[10,18]$.

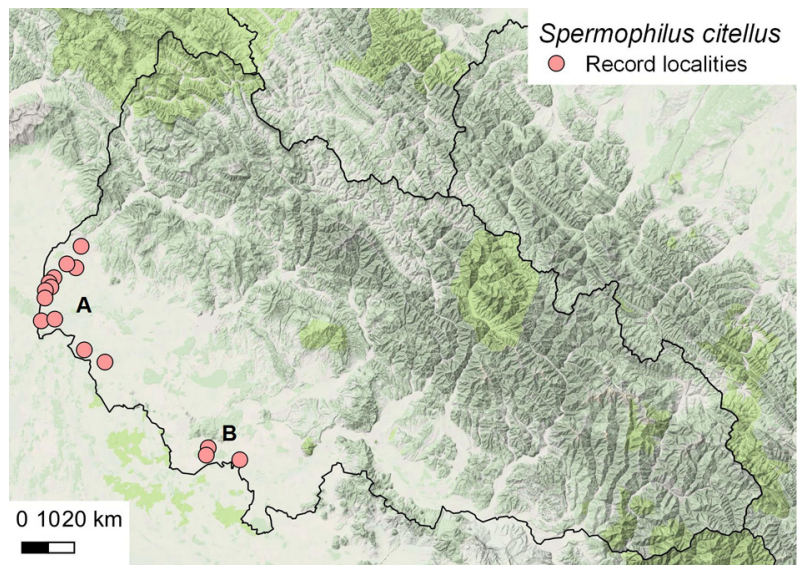

Fig. 4. Records of the European ground squirrel, S. citellus, in Transcarpathia in the western $(A)$ and southern $(B)$ range segments

Рис. 4. Знахідки ховраха європейського, S. citellus, на Закарпатті у західному (A) та південному (B) сегментах ареалу

The European ground squirrel is represented in the region by a very scarce population, which is concentrated in the northwest part of the Transcarpathian lowland (Uzhhorod Region). The species' distribution is related almost exclusively to anthropogenically transformed biotopes, mainly used as pastures. The vast majority of records is from the zones of former floodplains that were already dammed by the time of the species' first records (in 1964). Earlier, it was suggested that damming of floodplains could be playing a major role in either preservation of ground squirrel population or, basically, its emergence in the result of dispersal from neighbouring regions of Slovakia and Hungary [64].

ISSN 1996-4536 (print) • ISSN 2311-0783 (on-line) • Біологічні Студії / Studia Biologica • 2018 • Том 12/№3-4 • С. 75-94 
The current population decline and range contraction of S. citellus in Transcarpathia, which has been observed during recent decades, in our opinion, might be related to the decrease in livestock abundance leading to the contraction of the area of pastures and to their successional overgrowth.

Unlike the European ground squirrel, the common hamster has demonstrated a gradual increase in abundance and range, which could be related to the growing area of agricultural lands in the region. According to our database, the common hamster, similarly to the ground squirrel, has a mosaic distribution in Transcarpathia existing in a number of local settlements. Most of the records are known from the lowland parts of Uzhhorod and Mukachevo Regions, particularly from the area between the valleys of the Uzh and Latorica rivers. The other, smaller range segment is located between the valleys of the Tisza and Borzhava rivers in the south of the Transcarpathian lowland (Fig. 5). The two range segments are certainly isolated, particularly by the area of the former Szernye Mochar (i.e. Chornyi Mochar), a grand wetland complex, which currently, however, is substantially drained.

Available data show the contraction of the southern $(B)$ range segment, while in the western segment $(A)$ the abundance of hamsters has increased in the past 10-12 years. In particular, we have data on frequent sightings of hamsters by locals near their estates, as well as on catches of hamsters by domestic predators. For instance, in Korytniany, Uzhhorod Region cats could catch about 25 to 30 hamsters during summer around a single estate ( $\mathrm{V}$. Chumak, personal communication). In addition, frequent records of roadkills also evidence the increase in abundance, e.g. in summer 2007 the average number of roadkills on the $10 \mathrm{~km}$ long road section of Korytniany-Uzhhorod was 3-5 hamsters every morning (V. Chumak and R. Kish, personal communication).

Fig. 5. Records of the common hamster, C. cricetus, in Transcarpathia in the western $(A)$ and southern $(B)$ range segments

Рис. 5. Знахідки хом'яка звичайного, C. cricetus, на Закарпатті у західному (A) та південному (B) сегментах ареалу

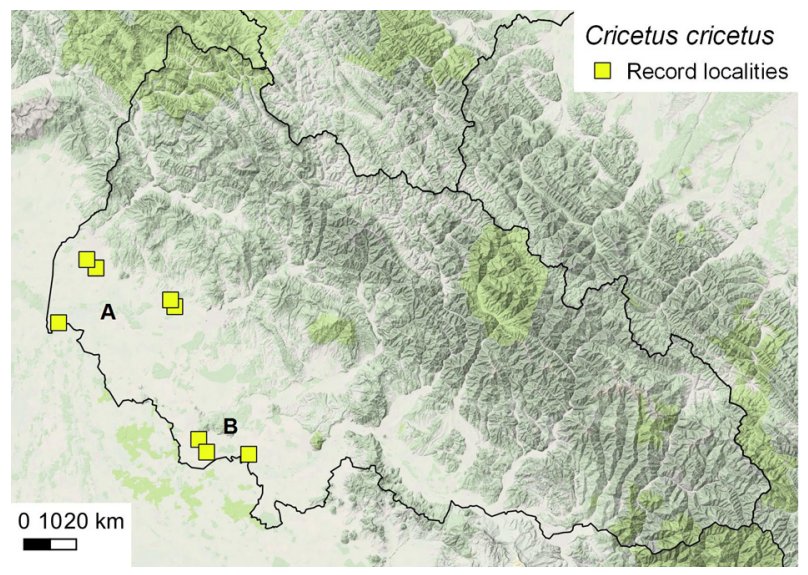

The growth in abundance of hamsters has been probably a temporal outbreak thus the general tendency of population decline still takes place and the species should be considered vulnerable in Transcarpathia. According to the Red Data Book of Ukraine [31], the reason for population decline of the common hamster in Ukraine is its extirpation by people. Indeed, during fieldworks in spring, hamsters may suffer large-scale extirpation (V. Chumak, personal communication), although, as we can see, even under the constant pressure of this factor the Transcarpathian population has managed to survive and even increase its abundance. In our opinion, the local hamster populations in both range

ISSN 1996-4536 (print) • ISSN 2311-0783 (on-line) • Біологічні Студії / Studia Biologica • 2018 • Том 12/№3-4 • С. 75-94 
segments are more threatened by a wide use of pesticides, which became a common practice during recent years.

Another important factor having influence on hamsters in case of population growth is the death of animals on roads, which has become usual in the western $(A)$ range segment (in particular, near Korytniany and Rakoshyno). Obviously, the species has no adaptations to roads as environmental factors, and animals die when crossing roads attempting to migrate to new sites. For comparison, during census of roadkills conducted in 2004 in Transcarpathia we did not find any dead hamsters [58], although we inspected roads that run through currently known localities. This also confirms the significant population outbreak of hamsters during at least the last 10 years.

The steppe mouse is a recently discovered thus a little known species in the Transcarpathian rodent fauna. The species appeared here in the early 2000 s and currently known records allow suggesting that the steppe mouse also has a mosaic distribution in the region having two range segments and, respectively, two routes of expansion from the neighbouring Slovakia and Hungary (Fig. 6). However, such hypothesis in the light of little available data is highly preliminary and new findings can be expected from other parts of the region.

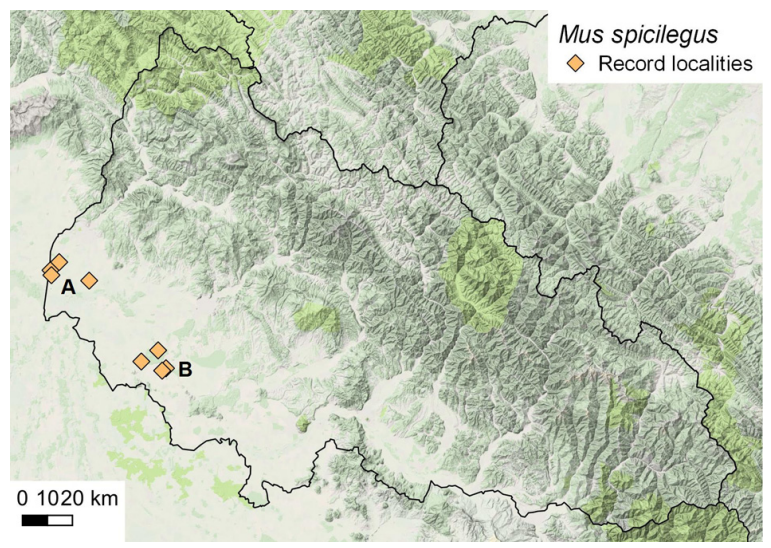

Fig. 6. Distribution of the steppe mouse, $M$. spicilegus, in Transcarpathia in the western $(A)$ and southern $(B)$ range segments

Рис. 6. Поширення миші курганцевої, M. spicilegus, на Закарпатті у західному (А) та південному (В) сегментах ареалу

A significant number of mounds revealed in each locality allows suggesting that the steppe mouse became a common species in areas of its occurrence. In Transcarpathia, the steppe mouse inhabits fallows, vineyards, and agricultural lands (corn, sunflower, and cereal fields) adapting to crop rotation. The examined content of mounds in vicinities of Hut, Berehovo Region revealed the absolute predomination of ears of perennial grasses, particularly of Setaria viridis. This concerns even mounds located directly on crop fields. Possible further range dynamics of the species in the region should be a subject of subsequent research.

Noteworthy, all three steppe species have generally similar outlines of their distribution range, as well as similar range fragmentation into two segments, western and southern (see Figs 4-6). The range of each species tends to the lowland parts of valleys of large rivers in the bordering areas of Transcarpathia.

\section{Range dynamics in the context of landscape transformation of the Transcarpathian lowland}

Landscape transformation, especially of anthropogenic origin, has a large impact on distribution patterns of steppe species. Being adapted to steppe and steppe-like 
biotopes, habitat loss leads to range contraction and fragmentation, especially on its edge. Among steppe species of Ukraine, such process takes place in the greater mole rat (Spalax microphthalmus), which population existing on the species range edge in Eastern Ukraine underwent significant fragmentation during the past few decades [65]. However, large-scale landscape transformation also can create new habitats on range peripheries suitable for emergence of new populations. In case of steppe species in Transcarpathia, we witness an example of the latter process.

All three steppe species occur in Transcarpathia in anthropogenically transformed biotopes and their abundance directly depends on human activity (decrease in cattle breeding and successional overgrowth of pastures, increase/decrease of the area of arable lands, use of plant protection chemicals, etc.). It begs the conclusion that distribution ranges of steppe species in the region are not natural but secondary. Moreover, the absence of natural populations in indigenous biotopes and, in fact, the absence of typical key steppe habitats suggest that steppe species appeared in Transcarpathia as the result of expansion from their main geographic range as suitable habitats gradually appeared at the range periphery.

Natural complexes of the Transcarpathian lowland sufficiently changed during the past two or three centuries, and the current landscape had been formed by the middle of the 20th century. This could also explain the former absence of currently known steppe species in the Transcarpathian mammal fauna. Landscape transformation occurred here in two main ways as the result of which unique animal and plant communities were lost. On the one hand, it was the large-scale deforestation [20,36]. On the other, it was the regulation of rivers with damming of streambeds, as well as the drainage of the Szernye Mochar (i.e. Chornyi Mochar) along with the Szernye Lake in its eastern part. Szernye Mochar was a grand wetland complex in the central part of the Transcarpathian lowland between the valleys of the Latorica and Tisza rivers (Fig. 7) and it was almost completely drained in the period from the 1870 s to 1950 s $[7,28]$. Both processes, i.e. deforestation and river regulation, led to the gradual increase of the area of disturbed and cultivated landscapes. Obviously, it contributed to the dispersal of steppe plant and animal species to Transcarpathia from the Great Hungarian Plain.

The natural reasons for emergence of the steppe mammalian assemblage in Transcarpathia could be related to the ecological plasticity of species in its composition. In particular, all three species occurring in the region show generalist tendencies allowing them to occupy suitable habitats that appear on range periphery.

An important biological feature of steppe species of Transcarpathia is also their way of wintering. All of the studied species, representing the northernmost steppe assemblages, have specific wintering adaptations practically allowing them to avoid the direct influence of factors of winter. The ground squirrel and the hamster hibernate in burrows, while the steppe mouse winters under the protection of mounds.

Analysis of species ranges shows that the common hamster is absent in the area of the former Szernye Mochar, while the European ground squirrel occurs locally only in its northwesternmost part. In our opinion, such distribution pattern is due to the annual amassment of water on significant areas of the former Mochar in winter or in spring (Fig. 8). Respectively, the water can fill up the burrows while the animals are hibernated thus being unable to escape and eventually dying.

Therefore, regular annual flooding is probably an important limiting factor for the ground squirrel and the hamster in the central part of the Transcarpathian lowland, while

ISSN 1996-4536 (print) • ISSN 2311-0783 (on-line) • Біологічні Студії / Studia Biologica • 2018 • Том 12/№3-4 • С. 75-94 


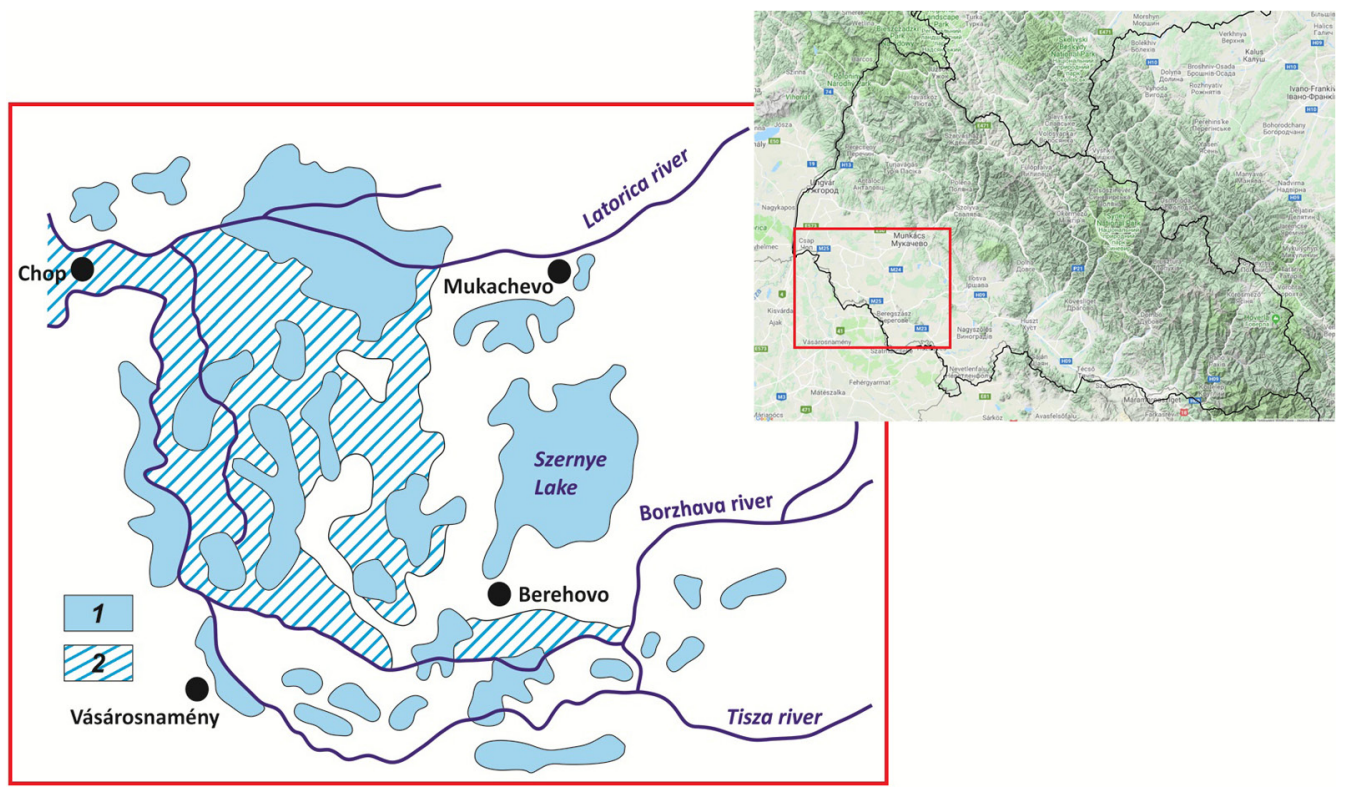

Fig. 7. The former Szernye Mochar wetland (drawn after S. Frisnyák in [7]), which was gradually drained between the 1870s and 1950s. Consequently, unique wetland complexes were lost in areas that constantly (1) or temporarily (2) were covered with water. Instead, agricultural lands, pastures and other secondary biotopes emerged, suitable for steppe species

Рис. 7. Колишній водно-болотний комплекс "Сернє мочар" (згідно з рисунком S. Frisnyák за: [7]), який поступово було осушено з 1870-х до 1950-х рр. У результаті знищено унікальні водноболотні комплекси на ділянках, що постійно (1) або періодично (2) перебували під водою. На їхньому місці виникли агроценози, пасовища й інші вторинні біотопи, придатні для існування степових видів

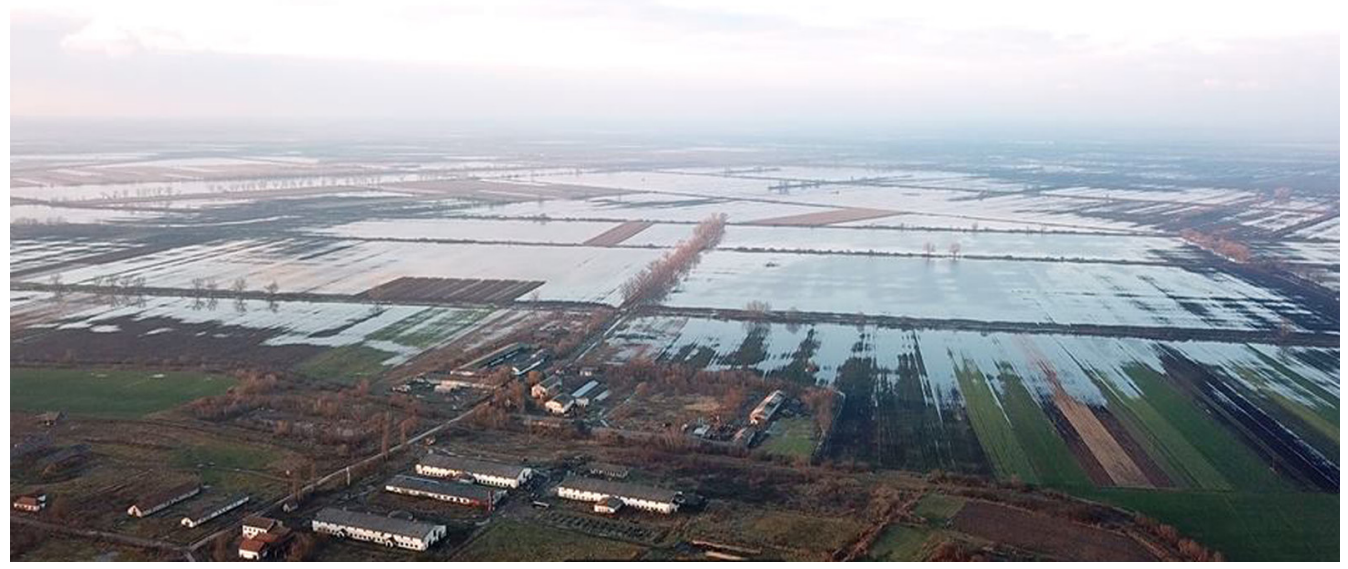

Fig. 8. Areal flood in the territory of the former Szernye Lake, a possible limiting factor of distribution of hibernating steppe mammal species in Transcarpathia. View from Nagybereg, December 2017. Courtesy of László Tóth

Рис. 8. Накопичення води на території колишнього озера Сернє - фактор, що, ймовірно, лімітує поширення зимосплячих степових ссавців на Закарпатті. Вигляд зі с. Великі Береги, грудень 2017 p. Фото: Ласло Товт

ISSN 1996-4536 (print) • ISSN 2311-0783 (on-line) • Біологічні Студії / Studia Biologica • 2018 • Том 12/№3-4 • С. 75-94 
it has less impact on the steppe mouse. The steppe mouse winters close to the surface and, since it does not hibernate, in case of flooding is able to get into safety in time, while the ground squirrel and the hamster are hibernating in burrows which can be suddenly flooded when the animals are sleeping. Settlements of the European ground squirrel and the common hamster in the southern part of the former Szernye Mochar (range segment B) exist in well-dammed and canalized areas where the influence of flooding is limited, just as the distribution of these species into neighbouring and periodically flooded areas, which can explain the species' restricted distribution in this part of the region.

\section{Protection and prospects of steppe species conservation}

Patchy distribution pattern has an important influence on population dynamics, in particular due to increasing of edge effects, limited gene flow in the result of isolation between separate segments and the main part of the species range, increasing of inbreeding, etc. $[11,15,16]$. As a result, the effective population size decreases that leads to reduction in natural population growth as well [44]. The influence of such processes probably takes place in the Transcarpathian part of the range of steppe species, which explains their low abundance and rarity, and, in the same time, makes topical the issue of their conservation. Currently, conservation issues especially concern two species, namely the European ground squirrel and the common hamster, which are keystone species in steppe and forest steppe ecosystems [56].

The current situation with $S$. citellus in Transcarpathia is critical due to contraction of the area of suitable habitats thus the species is close to extinction. In the latest edition of the Red Data Book of Ukraine, the species was already listed as extinct [32]. As proposed earlier [64], the most promising ways of restoration of the ground squirrel population in Transcarpathia could be the implementation of a complex of conservation measures including the artificial release of animals. However, the decline in the area of suitable habitats, in particular due to significant reduction of cattle breeding and of grazed pastures in the region, might prevent the ground squirrel's restoration. Further existence of the species in the region is practically impossible without creating protected areas with a respective level of grazing pressure.

As mentioned above, in recent years, local increase of the hamster's abundance had occurred on the background of general population decline in both Europe and Ukraine. The hamster is threatened in Transcarpathia due to its direct extirpation by people and domestic carnivores (probably by wild ones too), death on roads, use of plant protection chemicals, etc. The reduction of spring-sown cereals in favour of wintersown cereals can also affect the survival of population, since in case of reduced food supply females of the common hamster probably do not produce enough offspring for a sustainable population [27]. Yet in case of long-term preservation of current population trends, the expansion of the species' range could be expected in the region.

Currently, the steppe mouse is in the stage of range expansion and its dispersal in the region seems not to be limited by any obvious factor. Since the species is more common for agricultural lands, especially for field-edge habitats, human economic activity contributes to the species dispersal. The current dispersal of the steppe mouse in Transcarpathia is similar to its expansion northward in the main part of the species range in Ukraine, both in Podolia and in central and eastern Ukraine [19, 59].

Steppe species exist in Transcarpathia on the edge of their geographic range surrounded by the Carpathians. Ecotone effects and respective consequences at the junction

ISSN 1996-4536 (print) • ISSN 2311-0783 (on-line) • Біологічні Студії / Studia Biologica • 2018 • Том 12/№3-4 • С. 75-94 
of steppe, forest steppe, and mountain biotopes determine the biogeographic uniqueness of Transcarpathia as a model region in the study of co-existence of different faunal assemblages, in particular of steppe species alongside forest and mountain ones.

\section{ACKNOWLEDGEMENTS}

We would like to thank our colleagues V. Chumak, R. Kish (Uzhhorod University), N. Koval (Uzhanskyi National Park), and V. Gleba (Ukrainian Society for Bird Protection) for reporting important records of steppe species in Transcarpathia. We also acknowledge B. Dracskó, N. Mátyus, and T. Héder for reporting records and taking part in interviewing elderly locals. Special thanks to M. Macholán for his help in finding hardly available sources, as well as to L. Tóth for sharing his photograph of the flooded area of the former Szernye Lake. We further acknowledge O. Kovalchuk for proofreading the manuscript and V. Parkhomenko for improving the quality of pictures used in this paper.

1. Abelentsev V.I. Mustelids. Fauna of Ukraine. Volume 1. Mammals. Issue 3. Kyiv: Naukova Dumka, 1968. 280 p. (In Ukrainian).

2. Barkaszi Z., Zagorodniuk I. The taxonomy of rodents of the Eastern Carpathians. Proceedings of the State Natural History Museum, 2016; 32: 137-154.

3. Bashta A.-T, Potish L. Mammals of the Transcarpathian region (Ukraine). Lviv, 2007. 260 p. (In Ukrainian).

4. Benedek A.M. Small mammals (Insectivora and Rodentia) from the Agnita-Sighişoara area (Transylvania, Romania). Transylvanian Review of Systematical and Ecological Research, 2007; 4: 187-198.

5. Bihari Z. A güzüegér magyarországi elterjedése és építő tevékenységének jellemzői. Vadbiológia, 2003; 10: 107-114.

6. Bonhomme F., Catalan J., Gerasimov S., Orsini P., Thaler L. Le complexe d'espèces du genre Mus en Europe Centrale et Orientale. I. Génétique. Zeitschrift für Säugetierkunde, 1983; 48: 78-85.

7. Botlik J. Gát. Budapest: Száz magyar falu könyvesháza Kht, 2001. 233 p.

8. Čanády A., Mošanský L., Stanko M., Fricová J. Fauna drobných zemných cicavcov (Insectivora, Rodentia) Priemyselného parku Kechnec (Košická kotlina, Východné Slovensko). Natura Carpathica, 2007; 48: 153-162.

9. Čanády A., Mošanský L., Uličná L. Variability of skull and dental characteristics in Mus spicilegus from the northern border of its distributional range. Biologia, 2014; 69(10): 1425-1430. [DOI: https://doi.org/10.2478/s11756-014-0442-0]

10. Cserkész T. Az ürge (Spermophilus citellus) gyakoriságának változása Magyarországon 1950 és 2017 között. LIFE13NAT/HU/000183 számú “A kerecsensólyom és a parlagi sas táplálékbázisának megőrzése a Kárpát-medencében" LIFE+NATURE projekt A1 akciója. 2018. 25 p.

11. Donovan T.M., Jones P.W., Annand E.M., Thompson III F.T. Variation in local-scale edge effects: mechanism and landscape context. Ecology, 1997; 78(7): 2064-2075.

[DOI: https://doi.org/10.1890/0012-9658(1997)078[2064:VILSEE]2.0.CO;2]

12. Éhik Gy. A mezei görény (Mustela eversmanni Less.) hazánkban. Annales Musei Nationalis Hungarici, 1928; 25: 1-38.

13. Filipenko S. Records of the steppe polecat (Mustela eversmanni Lesson, 1827) in Ukraine: review of zoological collections. Proceedings of the Theriological School, 2014; 12: 102 107. (In Ukrainian).

14. Grulich I. Populationsdichte des Hamsters (Cricetus cricetus, Mamm.). Acta Scientiarum Naturalium Brno, 1980; 14(6): 1-44.

15. Hanski I., Ovaskainen O. Metapopulation theory for fragmented landscapes. Theoretical Population Ecology, 2003; 64(1): 119-127.

[DOI: https://doi.org/10.1016/S0040-5809(03)00022-4]

ISSN 1996-4536 (print) • ISSN 2311-0783 (on-line) • Біологічні Студії / Studia Biologica • 2018 • Том 12/№3-4 • С. 75-94 
16. Harris L. D. Edge effects and conservation of biotic diversity. Conservation Biology, 1988; 2(4): 330-332.

[DOI: https://doi.org/10.1111/j.1523-1739.1988.tb00196.x]

17. Heptner V.G. On some features of distribution of mammals in the European part of the Soviet Union. In: Kratochvíl, J., Obrtel, R. (Eds) Symposium Theriologicum II (Brno). Praha: Academia, 1974. P. 93-97. (In Russian).

18. Janák M., Marhoul P., Matějů J. Action plan for the conservation of the European ground squirrel Spermophilus citellus in the European Union. European Commission, 2013. $61 \mathrm{p}$.

19. Kondratenko A. V. The mound-building mouse, Mus spicilegus (Mammalia, Rodentia) in eastern regions of Ukraine. Proceedings of the Theriological School, 2006; 7: 63-66. (In Russian).

20. Konkoly-Gyuró É., Balázs P. Erdőborítás-változás a Kárpát-medence térségében a 19. század közepétől napjainkig. Erdészettudományi Közlemények, 2016; 6(1): 79-97. [DOI: https://doi.org/10.17164/EK.2016.007]

21. Korchinsky A. Rodents of the Ukrainian Carpathians (research results). In: Issues of protection and rational use of plants and animals of the Ukrainian Carpathians. Uzhgorod: MOIP, 1988. P. 156-173. (In Russian).

22. Korobchenko M., Zagorodniuk I. Taxonomy and levels of differentiation in mole-rats (Spalacidae) of the fauna of Ukraine and adjacent countries. Scientific Bulletin of Uzhgorod University, Series Biology, 2009; 26: 13-26. (In Ukrainian).

23. Krištofík J., Danko Š. Distribution of Mus spicilegus (Mammalia: Rodentia) in Slovakia. Lynx, Praha, n. s., 2003; 34: 55-60.

24. Kryštufek B. Spermophilus citellus (Linnaeus, 1766). In: Mitchell-Jones A.J., Amori G., Bogdanowicz W., Kryštufek B., Reijnders P.J.H., Spitzenberger F., Stubbe M., Thissen J.B.M., Vohralík V., Zima J. (Eds) The Atlas of European Mammals. London: Academic Press, 1999. P. 190-191.

25. Kuznetsov B.A. On some patterns of distribution of mammals in the European part of the Soviet Union. Zoologicheskii Zhurnal, 1936; 15(1): 96-127. (In Russian).

26. La Haye M.J.J., Neumann K., Koelewijn H.P. Strong decline of gene diversity in local populations of the highly endangered common hamster (Cricetus cricetus) in the western part of its European range. Conservation Genetics, 2012; 13(2): 311-322.

[DOI: https://doi.org/10.1007/s10592-011-0278-x]

27. La Haye M.J.J., Swinnen K.R.R., Kuiters A.T., Leirs H., Siepel H. Modelling population dynamics of the common hamster (Cricetus cricetus): timing of harvest as a critical aspect in the conservation of a highly endangered rodent. Biological Conservation, 2014; 180: 53-61. [DOI: https://doi.org/10.1016/j.biocon.2014.09.035]

28. Lehoczky T. Bereg vármegye monographiája. I kötet. Ungvár, 1881. $472 \mathrm{p}$.

29. Macholán M. Mus spicilegus Petenyi, 1882 in Transcarpathian Ukraine? A revision of Štépánek (1934). Časopis Národního muzea. Řada přírodovědná, 1995; 164: 33-37.

30. Magyari E.K., Chapman J.C., Passmore D.G., Allen J.R.M., Huntley J.P., Huntley B. Holocene persistence of wooded steppe in the Great Hungarian Plain. Journal of Biogeography, 2010; 37: 915-935.

[DOI: https://doi.org/10.1111/j.1365-2699.2009.02261.x]

31. Mezhzherin S.V. The common hamster Cricetus cricetus (Linnaeus, 1758). In: Akimov I.A. (Ed.) Red Data Book of Ukraine. Animals. Kyiv: Globalkonsalting, 2009 a. P. 531. (In Ukrainian).

32. Mezhzherin S.V. The European ground squirrel, Spermophilus citellus Linnaeus, 1766. In: Akimov I.A. (Ed.) Red Data Book of Ukraine. Animals. Kyiv: Globalkonsalting, 2009 b. P. 517. (In Ukrainian).

33. Mezhzherin S.V., Zagorodnyuk I.V. Morphological, karyological and genetic divergences of the house (Mus musculus musculus) and mound-building mice (Mus musculus hortulanus). In: Sokolov V. E. (Ed.) House Mouse. Moscow, 1989; P. 99-114. (In Russian).

34. Mezhzherin S.V., Lashkova O.I. Mammals of Ukraine. Kyiv: Naukova Dumka, 2013. 356 p. (In Ukrainian).

ISSN 1996-4536 (print) • ISSN 2311-0783 (on-line) • Біологічні Студії / Studia Biologica • 2018 • Том 12/№3-4 • С. 75-94 
35. Mojsisovich A. Az Osztrák-Magyar Monarchia állatvilága. In: Habsburg-Lothringen R. et al. (Eds) Az Osztrák-Magyar Monarchia írásban és képben. Budapest: Magyar Királyi Államnyomda, 1887. P. 253-338.

36. Munteanu C., Kuemmerle T., Boltiziar M., Butsic V., Gimmi U., Halada L., Kaim D. et al. Forest and agricultural land change in the Carpathian region - a meta-analysis of long-term pattern and drivers of change. Land Use Policy, 2014; 38: 685-697.

[DOI: http://doi.org/10.1016/j.landusepol.2014.01.012]

37. Nechay G., Hamar M., Grulich I. The common hamster (Cricetus cricetus [L.]): a review. EPPO Bulletin, 1977; 7(2): 255-276.

[DOI: https://doi.org/10.1111/j.1365-2338.1977.tb02727.x]

38. Neumann K., Jansman H., Kayser A., Maak S., Gattermann R. Multiple bottlenecks in threatened western European populations of the common hamster Cricetus cricetus (L.). Conservation Genetics, 2004; 5(2): 181-193.

[DOI: https://doi.org/10.1023/B:COGE.0000030002.01948.b3]

39. Prots B., Kagalo O. (Eds). Catalogue of habitat types of the Ukrainian Carpathians and Transcarpathian lowland. Lviv: Institute of Ecology of the Carpathians, 2013. 294 p. (In Ukrainian).

40. Ramos-Lara N., Koprowski J. L., Kryštufek B., Hoffmann I. E. Spermophilus citellus (Rodentia: Sciuridae). Mammalian Species, 2014; 46(913): 71-87.

[DOI: https://doi.org/10.1644/913.1]

41. Reshetnyk E.G. Systematics and geographical distribution of ground squirrels (Citellus) in the UkrSSR. Trudy Instytutu zoologii AN URSR, 1948; 1: 84-113. (In Ukrainian).

42. Reshetnyk E.G. The European ground squirrel (Citellus citellus L.) in Transcarpathia. In: Terrestrial Vertebrates of Ukraine. Kyiv, 1965. P. 122-123. (In Ukrainian).

43. Rusin M.Yu., Banaszek A., Mishta A.V. The common hamster (Cricetus cricetus) in Ukraine: evidence for population decline. Folia Zoologica, 2013; 62(3): 207-213.

[DOI: https://doi.org/10.25225/fozo.v62.i3.a6.2013]

44. Shaffer M.L. Minimun population sizes for species conservation. BioScience, 1981; 31(2): 131-134.

[DOI: https://doi.org/10.2307/1308256].

45. Skilsky I.V., Smirnov N.A., Meleshchuk L.I. Rare vertebrate animals. In: Korzhyk V.P. (Ed.). Khotyn Upland. Chernivtsi: Druk Art, 2012. P. 252-288. (In Ukrainian).

46. Sokur I.T. New data on the mammal fauna of Transcarpathia. Dopovidi AN URSR, 1949; 5: 83-91. (In Ukrainian).

47. Sokur I.T. Mammals of the Soviet Carpathians and their economic importance. Kyiv: AS UkrSSR, 1952. 68 p. (In Ukrainian).

48. Štěpánek O. Mus spicilegus Petényi v Československu. Sborník zoologické oddělení Národního Muzea v Praze, 1934; 1: 56.

49. Surov A., Banaszek A., Bogomolov P., Feoktistova N., Monecke S. Dramatic global decrease in the range and reproduction of the European hamster Cricetus cricetus. Endangered Species Research, 2016; 31: 119-145.

[DOI: https://doi.org/10.3354/esr00749]

50. Tatarynov K. A. Mammals of the western regions of Ukraine. Kyiv: AS UkrSSR, 1956. 188 p. (In Ukrainian).

51. Tews J., Brose U., Grimm V., Tielbölger K., Wichmann M. C., Schwager M., Jeltsch F. Animal Species diversity driven by habitat heterogenity/diversity: the importance of keystone structures. Journal of Biogeography, 2004; 31: 79-92.

[DOI: https://doi.org/10.1046/j.0305-0270.2003.00994.x]

52. Turianyn I. I. Fur-bearing and industrial mammals and game birds of the Carpathians. Uzhgorod, 1975. 176 p. (In Ukrainian).

53. Turianyn I.I. Current state of some cricetids in the territory between the upper courses of the Dniester and Tisza rivers. In: Cricetids of the Ukrainian Fauna. Preprint 7.87. Kyiv: Institute of Zoology AS UkrSSR, 1987. P. 3-9. (In Russian).

ISSN 1996-4536 (print) •ISSN 2311-0783 (on-line) • Біологічні Студії / Studia Biologica • 2018 • Том 12/№3-4 • C. 75-94 
54. Ulbrich K., Kayser A. A risk analysis for the common hamster (Cricetus cricetus). Biological Conservation, 2004; 117(3): 263-270.

[DOI: https://doi.org/10.1016/j.biocon.2003.12.006]

55. Volokh A.M. The current state of populations of the steppe polecat (Mustela eversmanni Lesson, 1827) in Ukraine. Scientific Bulletin of Uzhgorod University, Series Biology, 2004; 15: 105-109. (In Ukrainian).

56. Zagorodniuk I.V. Steppe fauna core of Eastern Europe: its structure and prospects of protection. Reports of the National Academy of Sciences of Ukraine, 1999 a; No. 5: 203-210. (In Ukrainian).

57. Zagorodniuk I. The common hamster - Cricetus cricetus. Proceedings of the Theriological School, 1999 b; 2: 144-148. (In Ukrainian).

58. Zagorodniuk I.V. Mortality of animals on roads: assessment of vehicle traffic's influence at populations of wild and domestic animals. Proceedings of the Theriological School, 2006; 8: 120-125. (In Ukrainian).

59. Zagorodniuk I.V., Berezovsky V.I. Mus spicilegus (Mammalia) in the fauna of Podolia and the northern border of its range in Eastern Europe. Zoologicheskii Zhurnal, 1994; 73(6): 110 119. (In Russian).

60. Zagorodniuk I.V., Emelyanov I.G. Taxonomy and nomenclature of mammals of Ukraine. Proceedings of the National Museum of Natural History, 2012; 10: 5-30. (In Ukrainian).

61. Zagorodniuk I., Filipchuk N. "Bern" species of rodents in the Red Data Book of Ukraine (Spermophilus citellus, Sicista subtilis, Spalax graecus). Proceedings of the Theriological School, 1999; 2: 152-162. (In Ukrainian).

62. Zagorodniuk I.V., Emelyanov I.G., Khomenko V.N. Estimation of taxonomic diversity in faunistic communities. Reports of the National Academy of Sciences of Ukraine, 1995; No. 7: 145-148. (In Russian).

63. Zagorodniuk I., Pokynchereda V., Kyselyuk O., Dovganych Ya. Theriofauna of the Carpathian Biosphere Reserve. Vestnik zoologii, 1997; Suppl. 5: 1-60. (In Ukrainian).

64. Zagorodniuk I.V., Zizda Ju.E., Drobotun O.V. Former geographical distribution of the ground squirrel Spermophilus citellus (Rodentia, Sciuridae) in the Transcarpathians (Ukraine). Vestnik Zoologii, 2010; 44(2): 183-188. (In Ukrainian).

65. Zagorodniuk I., Korobchenko M., Parkhomenko V., Barkaszi Z. Steppe rodents at the edge of their range: a case study of Spalax microphthalmus in the north of Ukraine. Biosystems Diversity, 2018; 26(3): 188-200.

[DOI: https://doi.org/10.15421/011829]

\section{ЖИТТЯ НА ГРАНІ: ОСОБЛИВОСТІ ПОШИРЕННЯ СТЕПОВИХ ССАВЦІВ HA ЗАКАРПАТTI (УКРАÏHA)}

\section{3. Баркасі, I. Загороднюк}

Національний науково-природничий музей НАН України вул. Богдана Хмельницького, 15, Київ 01030, Україна e-mail: zlbarkasi@ukr.net

Проаналізовано склад степового комплексу у складі теріофауни Закарпаття (Україна), що представлений трьома видами гризунів: ховрах європейський (Spermophilus citellus), хом'як звичайний (Cricetus cricetus) і миша курганцева (Mus spicilegus). Ці види раніше не розглядали у складі місцевої фауни або згадували їх лише у загальних списках, часто навіть з очевидними помилками ключових ознак і місць знахідок. У цій праці ми подаємо детальний опис поширення кожного степового виду, базуючись на знахідках цих видів у біоценозах та на їхніх екологічних 
і біогеографічних особливостях. Загалом, відомо про 13 місць спостережень Spermophilus citellus, 7 - Cricetus cricetus, 8 - Mus spicilegus. Також виявлено й описано загальні тенденції цих видів: усі три степових види трапляються на рівнинній частині Закарпаття, між долинами річок Латориця і Тиса та на прилеглих ділянках. 3'ясовано, що степові види на Закарпатті пов'язані з антропічно трансформованими біотопами: ховрах європейський переважно трапляється уздовж річок (дамбах у районах розливу) і на пасовищах, тоді як хом'як звичайний і миша курганцева пов'язані з агроценозами. Відсутність природних популяцій в автохтонних біотопах вказує на те, що степові види з'явилися на Закарпатті внаслідок експансії основного ареалу поширення у міру появи придатних для поселення оселищ на краї ареалу. Найближчий центр поширення кожного виду перебуває поза регіоном дослідження, власне на Середньодунайській низовині, а описані із Закарпаття знахідки $є$ маргінальними: вони нестабільні й належать до зон пульсації ареалу, що, у свою чергу, залежить від ландшафтно-кліматичних фракторів і поточних ландшафтних особливостей рівнинного Закарпаття. Стан і динаміка крайових популяцій степових видів на Закарпатті можуть бути значною мірою зумовлені гідрологічним режимом, умовами зимування, людською діяльністю тощо, а також "крайовими ефектами", що зазвичай мають місце у фрагментованих популяціях. Впливом таких процесів можна пояснити низьку чисельність і високий ступінь раритетності степових видів у регіоні, що, зокрема, актуалізує питання їхньої охорони. На сьогодні питання охорони особливо стосується двох видів, зокрема, ховраха європейського та хом'яка звичайного, які $є$ ключовими видами степових і лісостепових екосистем.

Ключові слова: степова фауна, гризуни, рідкісні види, біотопи, Закарпаття, Україна

Одержано: 17.10.2018

ISSN 1996-4536 (print) • ISSN 2311-0783 (on-line) • Біологічні Студії / Studia Biologica • 2018 • Том 12/№3-4 • С. 75-94 